Vidya Samhita : Jurnal Pelelitian Agama

Volume 7, Nomor 1, 2021. pp $1-9$

p-issn : 2460 - 3376, e-issn : $2460-4445$

https://www.ejournal.ihdn.ac.id/index.php/vs/index

\title{
KENSEP TRI HITA KARANA MENJAGA EKSISTENSI SUBAK DARI ANCAMAN ALIH FUNGSI LAHAN
}

\author{
OLEH \\ I Ketut Manik Asta Jaya \\ Universitas Hindu Negeri I Gusti Bagus Sugriwa Denpasar \\ Email Corresponding: astajayaketut@uhnsugriwa.ac.id
}

\begin{abstract}
ABSTRAK
Penulisan karya ilmiah ini bertujuan mengkaji lebih dalam tentang implementasi konsep tri hita karana, khsusnya dalam menjaga eksistensi subak dari ancaman alif fungsi lahan yang kini terjadi hampir di seluruh wilayah Bali. Penulisan karya ilmiah ini menggunakan metode studi pustaka, dengan melakukan kajian berdasarkan referensi atau literatur yang tersedia, terutama dari artikel-artikel yang dipublikasikan dalam berbagai jurnal ilmiah. Hasil penulisan karya ilmiah ini menunjukan konsep tri hita karana hingga kini masih menjiwai sistem subak di Bali. Hal ini terlihat dari setiap aktifitasnya tidak bisa terlepas dari aspek, pawongan, palemahan dan parhyangan. Pawongan meliputi peran krama subak sebagai garda terdepan melindungi kawasan subak dari alih fungsi lahan. Ketegasan krama subak dapat dituangkan dalam awig-awig subak baik tertulis ataupun lisan. Palemahan untuk memberikan arahan mengenai sikap subak dan krama untuk mengolah dan memanfaatkan sumber daya alam yang terbatas yang terdiri atas tanah atau lahan pertanian. Sumber daya air yang ada di Bali dimanfaatkan untuk berbagai keperluan, antara lain untuk irigasi, air bersih, dan industry. Unsur parhyangan meliputi aktivitas keagamaan yang ada di areal subak yang diwujudkan dengan adanya bangunan suci sebagai tempat manusia melakukan persembahyangan dan melakukan kegiatan upacara lainnya.
\end{abstract}

Kata kunci: Tri Hita Karana; Subak; Alih Fungsi Lahan.

\section{Pendahuluan.}

Bali merupakan salah satu provinsi di Indonesia terkenal karena karakteristik nilai budaya. Kehidupan masyarakat Bali juga didasarkan pada falsafah agama yang sudah dikenal sampai seluruh dunia. Salah satunya ialah konsep tri hita karana. Sebagai konsep untuk menjaga keharmonisan dengan sesame manusia, lingkungan dan Tuhan. Konsep ini diimplementasikan dalam berbagai kehidupan masryarakat Bali, tidak terkecuali dalam sektor agraris yang terakomodir dalam sistem subak. Sejak lama sistem subak telah mengatur pola 
pertanian di Bali. Subak sudah menjadi sistem warisan sejak zaman kerajaan yang hingga kini masih eksis diterapkan, bahkan hal ini sudah diakui oleh UNESCO.

Subak sebagai sistem pertanian yang ada di Bali juga tidak bisa terlepas dari penerapan konsep tri hita karana. Mulai dari subak merupakan suatu sistem organisasi petani dalam mengelola air irigasi bagi anggota-anggotanya yang mengelola lahan pertanian. Subak sebagai sebuah organisasi, memiliki pengurus dan peraturan, yang dikenal dengan istilah awig-awig, baik tertulis ataupun lisan. Sebagai organisasi kemasyarakatan yang khusus mengatur sistem pengairan sawah dalam bercocok tanam padi di Bali, subak juga menjunjung aspek prhayangan, yakni menjaga hubungan harmonis dengan Tuhan, melalui pemujaan di Pura Ulun Carik atau Pura Bedugul. Pura ini khusus dibangun para pemilik lahan dan petani yang diperuntukkan bagi dewi kemakmuran dan kesuburan yakni Dewi Sri.

Dalam setiap Subak biasanya terdapat Pura subak juga berfungsi sebagai tempat untuk memohon keselamatan dalam segala aktivitas pertanian, serta memohon agar hasil pertanian menjadi baik. Pura subak merupakan tempat pemujaan untuk memohon kesejahteraan bagi seluruh petani. Selain Pura subak, masing-masing petani dalam suatu subak juga memiliki tempat pemujaan pada lahan sawahnya masing-masing yang bernama Tugu atau sanggah catu.

Berdasarkan penjabaran tersebut dapat diartikan bahwa subak merupakan suatu lembaga masyarakat hukum adat yang memiliki karakteristik sosioagraris-religius. Subak dikatakan sebagai organisasi sosioagraris-religius, karena dalam berbagai aspek kegiatannya organisasi subak selalu menggunakan landasan falsafah kepercayaan dan keyakinan berupa sastra dan ajaran agama, baik berupa tradisi, ritual dan upacara-upacara keagamaan yang berkaitan dengan pertanian.

Subak yang menerapkan ajaran tri hita karana dapat ditemukan dan tersebar pada hampir seluruh wilayah yang ada di Bali, untuk mengatur tata air di tingkat paling bawah dari sistem irigasi. Subak sebagai cikal bakal dari berbagai budaya di Bali sudah menjadi asset yang harus selalu dilestarikan. Subak juga memberikan nilai estetik dengan terasering petak sawah, termasuk kegiatan para petani dalam membajak, menuai hingga massa panen. Hampir seluruh proses dalam aktifitas pertanian memiliki nilai estetik. Hal ini terbukti dari banyaknya karya seni para seniman lokal ataupun international yang menjadi subak sebagai objek berkesenian. Wisatawan domestik hingga manca negara pun sengaja datang ke Bali, untuk menyaksikan langsung keindahan kawasan persawahan di Bali yang tertata oleh sistem subak.

Seiring dengan perkembangan zaman, timbul berbagai masalah yang dapat mengancam kelangsungan sistem organisasi subak, seperti beberapa daerah yang dulunya merupkan lumbung padi, namun kini harus digerus oleh alih fungsi lahan. Ancaman alih fungsi lahan terjadi hampir di seluruh wilayah di Bali. Sampai saat ini ancaman ini belum dapat ditangani secara optimal. Padahal permasalahan alih fungsi lahan yang tidak terkentrol, jelas tidak hanya mengancam eksistensi subak, namun kedepan juga menjadi ancaman untuk berbagai aspek kehidupan. Tidak hanya menjadi ancaman bagi alam lingkungan, juga akan berdampak pada ancaman untuk umat manusia. Berdasarkan data Dinas Pertanian Provinsi Bali, mencatat alih fungsi lahan di Bali relatif tinggi yakni mencapai 700 hektar pertahun. (Balipost, 2020).

Berdasarkan penjabaran tersebut dapat diartikan bahwa menjaga kawasan pertanian yang diatur dalam sistem subak menjadi hal penting untuk dilakukan. Terutama sistem subak 
yang berlandaskan pada konsep tri hita karana. Berdasarkan hal ini pula timbulah keinginan untuk Menyusun karya tulis terkait menjaga eksistensi subak dari alih fungsi lahan, terutama dengan mendasarkan pada konsep tri hita karana. Permasalahan ini juga menarik untuk diulas lebih khusus dalam bidang sosiagraris-religius pertanian dalam bentuk pelestarian nilai- nilai pendidikan keberagamaan. Hal ini penting karena pertanian, tidak hanya menyangkut kehidupan para petaninya, namun juga berkaitan erat dengan pelestarian alam, serta hubungan harmonis dengan Tuhan.

Tinjauan Pustaka/Teoritis

\section{PEMBAHASAN}

\subsection{Eksistensi Subak}

Sistem subak di Bali sesungguhnya sudah sangat berkembang, ini dibuktikan dengan dibangunnya bendungan untuk pengairan irigasi lahan pertanian. Hal ini juga membuktikan bahwa subak mampu mendayagunakan air berdasarkan asas keselarasan dengan alam, sesuai dengan konsep Tri Hita Karana yang melandasi lembaga subak di Bali.

Subak merupakan bagian integral dalam kebudayaan Bali, sementara agama Hindu yang melandasi kebudayaan Bali juga mewarnai seluruh aktivitas di dalam subak itu sendiri. Penegasan ini bahwa subak bagi masyarakat Bali khususnya bagi para petani berperanan sangat penting dalam kehidupan mereka. Berdasarkan hal tersebut subak berfungsi sebagai pengelolaan air dan fungsi mewujudkan kesejahteraan masyarakat. Terkait dengan fungsi subak sebagai pengelola air atau fungsi pengelola irigasi, subak sendiri memang merupakan sebuah sistem irigasi. Sebagai sistem irigasi, subak memiliki jaringan irigasi seperti bangunanbanguna yang diperlukan untuk pengaturan air irigasi mulai dari sumber air sampai ke petakpetak sawah yang di miliki para anggota subak. Fasilitas irigasi tersebut terdiri dari saluransaluran irigasi beserta bangunan-bangunan irigasi yang merupakan satu kesatuan jaringan irigasi. Fungsi subak sebagai pengelola air bisa dibuktikan dengan lebih tegas lagi melalui keberadaan berbagai saluran irigasi subak yang ditata sedemikian rupa sehingga setiap petak sawah dari hulu saluran irigasi hingga hilir mendapatkan pembagian air memadai.

Istilah untuk menyebut saluran dan bangunan irigasi berbeda antara subak satu dan subak lain di suatu daerah dan antara daerah lain di Bali. Misalnya, saluran-saluran yang di bawah tingkat saluran tersier (pemaron cenik) di beberapa tempat sering di sebut telabah penyahcah (saluran kuarter) atau telabah pengalapan. Telabah Pengutangan adalah saluran untuk mebuang air yang berlebih saluran pembuangan air untuk subak-subak di Bali seringkali di gabung dengan saluran pembawa. Ini di sebabkan karena tidak sedikit saluran pembawa yang hanya memanfaatkan alam. (Sutawan, 2008: 57-60).

Pengaturan irigasi dalam model subak dilakukan sedemikian rupa sehingga dari hulu hingga hilir setiap petak sawah teraliri secara merata. Ini berarti tidak memberikan kemungkinan air berlebih pada sawah yang dekat atau di samping saluran primer, sebaliknya juga tidak menciptakan difisit air bagi sawah- sawah yang jauh dari saluran utama. Sungguh suatu model pengelolaan air yang sangat adil dan bijaksana, meskipun dilakukan dengan cara-cara tradisonal. Terkait dengan fungsi subak sebagai pengelola air ini, fungsi subak sebagai pengelola air memang nyata terjadi dan di laksanakan serta di rasakan manfaatnya oleh anggota subak. Subak sebagai suatu lembaga dengan fungsi sebagai mengelola air, 
khususnya untuk irigasi persawahan, subak subak memang subuah organisasi yang sangat maju dengan penciptaan keadilan dan kesamarataan distribusi air.

Keberadaan subak bagi umat Hindu khusunya dan masyarakat Bali pada umumnya adalah dalam rangkan mensejhterakan masyarakat itu sendiri. Dalam konteks ini, Wayan Windia (2006:5) mengatakan bahwa sistem irigasi subak pada dasarnya adalah suatu lembaga adat yang berfungsi untuk mengelola air irigasi untuk kepentingan kesejahteraan masyarakat (petani).

Keadaan sejahtera akan dicapai jika subak, yang adalah salah satu aspek atau lembaga yang dibentuk dalam rangka kesejahteraan itu, di dalam dirinya memang ada peluangpeluang bagi masyarakat mewujudkan kesejahteraan, ada aktifitas atau kegiatan-kegiatan mewujudkan kesejahteraan dan masyarakat mengalami peningkatan kesejahteraan mereka melalui keanggotaan mereka di dalam subak. Dari informasi dan data yang telah penulis sajikan terkait dengan fungsi subak, sangat nyata terlihat bahwa seluruh aktivitas dan kegiatan di dalam organisasi subak, apakah itu berkaitan dengan berbagai pengaturan irigasi pola tanam dan aneka ritual keagamaan terkait dengan itu, seluruhnya dalam rangka kemanfaatan yang setinggi tingginya bagi hidup dan kehidupan serta kesejahteraan anggota subak itu sendiri.

Terkait dengan itu I Wayan Alit Artha Wiguna dan Sang Putu Kaler Surata (2008:11) menyatakan bahwa tugas utama subak adalah memenuhi segala kebutuhan fisik dan sosial spiritual anggota subak terkait dengan usha tani yang di kelola anggotanya. Lebih jauh, Sutawan (2008:134) mengatakan bahwa subak perlu dikembangkan menjadi lembaga irigasi yang berorientasi ekonomi. Ini dimaksudkan dalam rangka memenuhi kebutuhan ekonomi anggotanya. Sementara Sumarta, sebagaimana di kutif I Wayan Alit Artha Wiguna dan Sang Putu Kaler Surata (2008:10) menyatakan bahwa subak memiliki fungsi: 1) keterbukaannya menerima dan menyukseskan program pemerintah; 2) mendukung pembangunan sektor kepariwisataan di pusat-pusat tujuan wisata di Bali.

Pendapat Artha Wiguna dan Kaler Surata perlu di sampaikan di sini karena pada dasarnya program-program pemerintah dalam hubungannya dengan subak adalah programprogram pemberdayaan subak yang hilirnya adalah peningkatan kesejahteraan anggota subak dan masyarakat pada umumnya. Sementara daya dukung subak terhadap sektor pariwisata juga memiliki korelasi dengan perwujudan kesejahteraan masyarakat. Hal ini jika subak benar-benar bisa dikembangkan dengan baik, dia sesungguhnya merupakan lembaga irigasi yang sangat unik dan khas Bali. Ini bisa menjadi nilai jual buat Bali bagi para wisatawan. Semakin banyak wisatawan yang datang tentu akan meningkatkan pendapat daerah, yang imflikasinya juga akan memberi kemampuan kepada pemerintah untuk meningkatkan kesejahteraan masyarakat.

Namun demikian kesejahteraan tidak di ukur dari aspek ekonomi saja. Kesejahteraan juga mencakup situasi batin yang enak serta perasaan yang harmoni dan nyaman ketika relasirelasi yang di bangun, baik dengan Tuhan, dengan sesama, maupun dengan lingkungan alam berjalan dengan baik. Dalam kaitan ini, sebagaimana telah penulis kemukakan, sesungguhnya seluruh aktivitas dan kegiatan-kegiatan di dalam subak terkait dengan kesejahteraan model itu. Situasi di lapangan memang menunjukan bahwa secara nyata, dengan keberhasilan panen dengan jangka waktu tertentu, minimal kebutuhan pangan masyarakat terpenuhi, lebih dri 
itu, hasil panen bisa juga dijual yang sudah barang tentu merupakan penghasilan bagi petani atau anggota subak yang akan membantu meningkatkan daya beli mereka. Sementara di sisi lain, kesejahteraan batiniah juga tercipta karena kepuasan hasil panen, hubungan baik terhadap Tuhan melalui berbagai ritual keagamaan, rasa nyaman dalam hubungan dengan sesama melalui semangat kebersamaan dan kegotongroyongan, damai dengan hubungan alam sekitar karena seluruh wilayah persubakan dikelola dan ditata dengan baik sehingga merupakan hamparan lahan yang menentramkan sekaligus memberikan manfaat.

\subsection{Tri Hita Karana dalam Sistem Subak}

Sebagaimana dipahami bersama bahwa landasan yang dipergunakan sistem subak dalam mengelola organisasinya adalah landasan harmoni dan kebersamaan, yang merupakan perwujudan universal dari konsep Tri Hita Karana yang menjiwai sistem subak di Bali. Dinamika sosioreligius yang erat kaitannya dengan parhyangan, pawongan, dan palemahan masih tetap tampak melandasi perilaku petani di subak. Masyarakat subak selalu berusaha menjaga dan meneruskan kebiasaan-kebiasaan upacara-upacara yang ada kaitannya dengan kegiatan subak. Masyarakat petani juga berusaha untuk menjaga hubungannya antar masyarakat petani melalui aktivitas gotong royong. Demikian juga halnya dengan pelestarian lingkungannya, dengan setiap saat berusaha memelihara palemahan sawahnya agar asri dan berfungsi sesuai dengan yang diharapkan (Windia, 2006:45).

Hal senada juga diungkapkan Pitana (1997:2) menyatakan bahwa subak juga berdasarkan atas filosofi Tri Hita Karana yang mengajarkan bahwa kebahagiaan manusia akan dapat dicapai bila manusia mampu menjaga keharmonisan hubungan antara tiga faktor dari Tri Hita Karana. Windia (2006:13) menyatakan bahwa subak yang berlandaskan Tri Hita Karana adalah merupakan sistem yang bersifat sosio-teknis, yang teknologinya telah menyatu dengan sosio kultural masyarakat setempat.

Dengan demikian, keberadaan Subak dilandasi oleh konsep Tri Hita Karana yang terdiri atas parhyangan, pawongan, dan palemahan. Bagian-bagian tersebut pada dasarnya saling terkait dan berhubungan antara yang satu dengan yang lainnya, seperti organ tubuh manusia yang memiliki ketergantungan antara yang satu dengan yang lainnya yang menunjukkan eksistensi Subak.

\section{A. Aktivitas Keagamaan pada Subak (Parhyangan)}

Parhyangan merupakan hubungan antara manusia dengan Tuhan Yang Maha Esa (Sudarta, 2005:84). Parhyangan berasal dari kata Hyang yang berarti Tuhan. Parhyangan berarti Ketuhanan atau hal-hal yang berkaitan dengan keagamaan dalam memuja Ida Sang Hyang Widhi (Mandia, dkk, halaman 1). Unsur parhyangan meliputi aktivitas keagamaan yang ada di areal subak yang diwujudkan dengan adanya bangunan suci sebagai tempat manusia melakukan persembahyangan dan melakukan kegiatan upacara lainnya. Windia (2006:16) menyatakan bahwa pura yang dibangun di areal subak merupakan simbol tempat pemujaan kepada Tuhan Yang Maha Esa yang dianggap sebagai bagian dari mekanisme pengawasan terhadap sistem pengelolaan air yang dilakukan oleh subak.

Selain dari Pura Subak, terdapat sebuah bale subak yang memiliki beragam fungsi. Para krama memanfaatkan fungsi bale subak ini untuk membuat sarana upakara dalam pelaksanaan

kegiatan keagamaan. Tradisi dan nilai-nilai sosial budaya utamanya ritual keagamaan yang 
erat kaitannya dengan budidaya padi mempunyai peranan penting dalam membangun kebersamaan dan keharmonisan serta kestabilan sosial dalam komunitas pertanian dan pedesaan, yang dapat mendorong terjadinya kerjasama dalam melakukan pemeliharaan jaringan irigasi.

Dengan demikian pelaksanaan upacara keagamaan dilaksanakan oleh seluruh krama Subak sehingga semua krama bisa berkumpul yang dapat mendorong terpeliharanya kerjasama di antara krama Subak. Hal ini karena pelaksanaan kegiatan keagamaan yang dilaksanakan di subak sesuai dengan keberadaan subak yang bercorak sosial-agraris-religius yang memerlukan dukungan krama untuk menyelenggarakan kegiatan keagamaan.

Dengan demikian keberadaan pura Subak ini memiliki peranan penting terhadap kelangsungan pertanian di Subak. Tempat suci ini sering digunakan dalam melakukan upacara keagamaan untuk memohon perlindungan serta memuja Ida Sang Hyang Widhi Wasa dalam manifestasi-Nya sebagai Dewi Sri.

\section{B. Keadaan Krama dan Kehidupan Sosial (Pawongan)}

Pawongan adalah hubungan antara manusia dengan manusia (Sudarta, 2005:86). Pawongan berasal dari kata wong (dalam Bahasa Jawa Kuno) yang berarti orang (Mandia, dkk, halaman 1). Dalam hal ini, unsur Pawongan meliputi keadaan krama, struktur kepengurusan, dan kehidupan sosial. Menurut Sudarta (2005:87), anggota suatu subak adalah petani pemilik penggarap atau penggarap sawah dan sawah yang digarap itu berlokasi di wilayah subak yang bersangkutan. Persyaratan menjadi krama Subak di Bali hampir sama, yaitu berdasarkan atas ikatan kesatuan wilayah pertanian yang memperoleh air dari satu sumber. Menurut Pitana (1997:6) apabila dilihat dari segi partisipasi anggota dalam kegiatan-kegiatan subak, dapat dibedakan menjadi tiga kelompok, yaitu sebagai berikut.

1. Krama pengayah (anggota aktif) adalah anggota yang berpartisipasi secara aktif dalam semua kegiatan subak melalui mekanisme gotong royong seperti gotong royong, pemeliharaan dan perbaikan fasilitas subak (empelan, saluran, bangunan bagi dan fasilitas subak lainnya), aktif dalam upacara-upacara keagamaan yang dilakukan oleh subak maupun rapat-rapat subak.

2. Krama pengampel atau krama pengoot (anggota pasif) yaitu anggota subak yang karena alasan-alasan tertentu tidak terlibat aktif dalam kegiatan-kegiatan (ayahan) subak. Sebagai gantinya, anggota ini membayar dengan sejumlah beras (atau uang) yang disebut dengan pengoot atau pengampel.

3. Krama leluputan (anggota khusus), yaitu anggota subak yang dibebaskan dari berbagai kewajiban subak, karena yang bersangkutan memegang jabatan tertentu di dalam masyarakat seperti pemangku, bendesa adat, perbekel, ataupun sulinggih.

Seperti halnya kelompok atau organisasi lain, subak juga memiliki struktur untuk mengatur diri dalam upaya untuk mencapai tujuan yang diinginkan. Windia (2006:16) menyebutkan bahwa struktur organisasi subak berbeda pada setiap subak, tergantung dari luasnya areal subak, ketersediaan air irigasi, dan kegiatan yang harus dilakukan subak yang bersangkutan. Pitana (1997:7) menegaskan Subak mempunyai unsur pimpinan yang disebut prajuru yang umumnya terdiri atas pekaseh (ketua subak), petajuh (wakil pekaseh), penyarikan (sekretaris), petengen atau juru raksa (bendahara), juru arah atau kasinoman (penyalur informasi), 
dan saya (pembantu khusus).

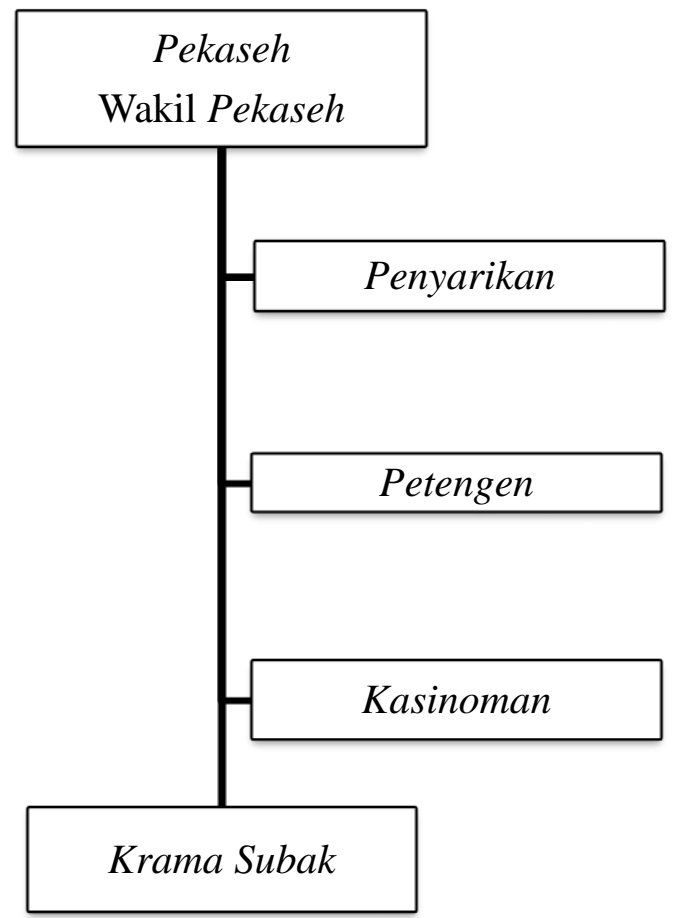

Struktur organisasi Subak

Prajuru Subak dipilih secara rutin setiap lima tahun sekali. Pemilihan prajuru subak diikuti oleh seluruh krama subak dalam suatu rapat khusus untuk untuk memilih prajuru subak. Jabatan juru arah atau kasinoman tidak dipilih pada saat rapat melainkan dilakukan secara bergilir setiap bulan di antara krama Subak. Subak juga memiliki awig-awig (peraturan) baik tertulis maupun tidak tertulis yang dibuat dan disepakati bersama oleh anggota subak melalui rapat subak. Awig-awig subak itu bersifat fleksibel, dalam arti selalu disesuaikan dengan perkembangan jaman (Sudarta, 2005:89).

Awig-awig mengatur tentang pelaksanaan upacara agama, bagi yang melanggar kesepakatan, mengatur tentang tugas prajuru subak, dan lain-lain, sehingga dengan adanya awig-awig lembaga subak menurut Windia (2006:17) bisa berjalan sesuai dengan tujuan lembaga tersebut, yakni mengelola sistem irigasi berdasarkan harmoni dan kebersamaan. Dalam upaya menjaga eksistensi subak, para krama subak dapat mencantumkan ketegasan menjaga kawasan dari alih fungsi lahan pada awig-awig yang sudah disepakati. Aturan terkait tidak diperbolehkan melakukan alih fungsi lahan dalam awig-awig sesungguhnya sudah mulai dilakukan oleh sejumlah subak di Bali. Aturan ini juga bisa diperkuat dengan kolaborasi bersama desa adat, yang mencantumkan awig-awig serupa. Sehingga dalam upaya melindungi kawasan subak, para petani tidak berjuang sendiri, melainkan juga ada peran desa adat yang dilibatkan untuk menjaga kawasan subak. 


\section{Kondisi Lingkungan Subak (Palemahan)}

Sudarta (2005: 92) mengemukakan konsep palemahan untuk memberikan arahan mengenai sikap subak dan krama untuk mengolah dan memanfaatkan sumber daya alam yang terbatas yang terdiri atas tanah atau lahan pertanian. Sumber daya air yang ada di Bali dimanfaatkan untuk berbagai keperluan, antara lain untuk irigasi, air bersih, dan industri. Disektor pertanian, pemanfaatan air yang paling besar adalah untuk kebutuhan air irigasi. Pada umumnya disuplai dari air permukaan khususnya air sungai yang diambil dengan membangun bendung melintang sungai. Air kemudian disalurkan melalui bangunan pengambilan kemudian diatur oleh organisasi subak (Norken, 1997:54).

Secara umum, subak-subak yang ada di Bali mendapat air dari sungai, dimana aliran air dialihkan ke saluran (telabah) atau terowongan dengan membuat bendungan (empelan) (Norken, 1997:57).

Penggunaan pupuk dan obat-obatan dari bahan-bahan kimia seperti itu dapat mencemari lingkungan dan menghasilkan produk pangan yang tidak aman bagi kesehatan manusia dan hilangnya keanekaragaman hayati di lahan sawah berarti akan mengurangi sumber pendapatan mereka. Selanjutnya apabila terjadi kerusakan DAS (Daerah Aliran Sungai) akibat pembabatan hutan yang tidak bertanggung jawab dan pencemaran air sungai ataupun saluran irigasi di hulu, misalnya karena limbah beracun dari industri garmen, hotel dan sumber-sumber lainnya maka kelestarian subak akan terancam (Sutawan, 2008:3).

Keberadaan Subak memiliki peran yang penting terhadap keberadaan lahan pertanian di Bali. Seperti yang telah dijelaskan sebelumnya bahwa alih fungsi lahan tiap tahunnya semakin meningkat sehingga subak memiliki peranan yang besar dalam melestarikan lahan pertanian. Subak dan lahan pertanian di dalamnya merupakan suatu kesatuan karena lahan pertanian yang merupakan aspek palemahan dalam sistem subak. Lahan pertanian atau aspek palemahan sebagai produksi pangan merupakan konsumsi masyarakat luas. Dengan kata lain, keberadaan lahan pertanian dalam sistem persubakan sangatlah penting.

\section{Kesimpulan.}

Berdasarkan hasil analisis yang dijabarkan dalam penulisan karya ilmiah ini, maka dapat disimpulkan bahwa; 1) Subak sebagai bagian integral dalam kebudayaan Bali, sementara agama Hindu yang melandasi kebudayaan Bali juga mewarnai seluruh aktivitas di dalam subak itu sendiri. Penegasan ini bahwa subak bagi masyarakat Bali khususnya bagi para petani berperanan sangat penting dalam kehidupan mereka. Berdasarkan hal tersebut subak berfungsi sebagai pengelolaan air dan fungsi mewujudkan kesejahteraan masyarakat. 2) keberadaan Subak dilandasi oleh konsep Tri Hita Karana yang terdiri atas parhyangan, pawongan, dan palemahan. Bagian-bagian tersebut pada dasarnya saling terkait dan berhubungan antara yang satu dengan yang lainnya, seperti organ tubuh manusia yang memiliki ketergantungan antara yang satu dengan yang lainnya yang menunjukkan eksistensi Subak. 


\section{DAFTAR PUSTAKA}

Sutawan, Wayan.2008. Organisasi dan Manajemen Subak di Bali. Denpasar: PT. Offset BP Denpasar

Mertawan, I Dewa Nyoman. Tradisi-tradisi Agama Hindu pada Sistem Persubakan di Bangli (Studi Kasus Subak Tampuagan Desa Peninjoan Kecamatan Tembuku Kabpaten Bangli) (Skripsi). Denpasar: IHDN Denpasar.

Sirtha, Nyoman. 2007. Subak Konsep Pertanian Relegius. Surabaya : Paramita.

Sutawan, Wayan.2008. Organisasi dan Manajemen Subak di Bali. Denpasar: PT. Offset BP Denpasar

Wiana, I Ketut. 2007. Tri Hita Karana Menurut Konsep Hindu. Surabaya: Paramita.

Tanaya, I Wayan. Implementasi Tri Hita Karana dalam Revitalisasi Pertanian Subak Abian Pertiwi Palasari di Desa Ban Kecamatan Kubu (Skripsi). Denpasar: IHDN Denpasar.

Windia. 2006. Transformasi Sistem Irigasi Subak Yang Berlandaskan Konsep Tri Hita Karana. Denpasar : Pustaka Bali Post

https://www.balipost.com/news/2020/01/17/99216/Alih-Fungsi-Lahan-Pertaniandi...html\#: :text=DENPASAR\%2C\%20BALIPOST.com 